\title{
The Representation of Islam Identity on the Commercial TV's Advertisements
}

\author{
Ida Rosida \\ Syarif Hidayatullah State Islamic University Jakarta, \\ Indonesia \\ idarosida@uinjkt.ac.id
}

\author{
Sulhiah Wulan Sari \\ Department of English, Bina Sarana Informatika \\ Jakarta, Indonesia \\ sulhizah.szwebsi.ac.id
}

\begin{abstract}
This article discussed the use of veil by Indonesian Muslim women which was presented in the commercial TV'S advertisement. This study aimed at revealing the representation of Islam identity through Indonesian veiled women on the commercial television's advertisement. This study w a s descriptive qualitative by using cultural studies approach that applied in the concept of representation, identity by Stuart Hall, gender and the ideological view on patriarchy. The compiled data was limited to two commercial TV'S advertisements; Wardah make up and Resik-V Manjakani intimate wash. The result showed that the veiled women on the two advertisements represented the modesty, piety, and modernity in wearing veil as the parts of Islam identity. Modesty involved the obedience on following the religion instruction and the Islamic values in social life especially on how Muslim women should dress (covering their body and hair; aurat). Piety could be both religious values in Islam (involved covering aurat) and patriarchal ideology stressed on the ideal Muslim women from the male's perspective (husband). Modernity referred to the development of fashion Muslim women in Indonesia, especially on how the veiled women used a certain style of veisl either for their daily activity or any special occasions. In conclusion, the two advertisements in representing the Islam identity through Indonesian veiled women were projected and legitimized by the ideology of patriarchy. Moreover, it was the effect of social construction in generalizing that a good women or good wives were those who can give the pleasure for their husband.
\end{abstract}

Keywords - Representation; Islam Identity; Indonesian Veiled Women; Advertisement

\section{INTRODUCTION}

Veil or Jilbab, Hijab, Khimar, Jaybs is one of the effects of Islamization and globalization process [8]. The effect of it then leads to the emergence of increasing number of veiled women in Indonesia; either teenagers, young adults or old women. Veiling becomes a great phenomenon as it does not only refer to Islam identity, but also how the veil as an artifact (culture embodiment) or commodity leads to a popular culture. It is said by El- Bassiouny that veil is not only as a symbol of religious practices but also contains a lot of cultural connotation. There are many factors influencing this including the development of fashion Muslim and veil industry, and the role of electronic media like religious film and TV's advertisement [3]. According to Ghani in Hassan, this is caused by the development of fashion Muslim media, blogs, designer, and retailer [4]. Beta said that the use of veil in Indonesia is completely fashionable as the effect of trend fashion promoted by the fashion designer like Dian Pelangi [2]. Barnard asserted that veil symbolizes the life style of modernity in the religious [1]. In this case, veil could be categorized as a pop culture as the use of it is not only influenced by the religious views but also the context of capitalist culture. In this context, veil becomes illimitable desire of commodity and consumption.
In another side, veil as a part of Islam identity is a set of cultural practices, (see 'cultural practice' in Hall) which brings the meaning through its representation in the commercial TV's advertisement [5]. As the function of culture is to produce and circulate meaning [7], then it plays a part in constructing Islam identity (veil) that applies in advertisement. The advertisement on television is not only a part of media persuading the viewers to be involved in consumption but also it can change attitude, belief, opinion, or someone's behavior as stated by Larson in Ihza [6]. According to Chaney in Rosida, advertisement is a channel of desire [10]. In case of veil which is represented on TV's advertisement, it has a great effect for the viewer's predominantly to stimulate their desire to consume the veil as a commodity and also the Islamic values on the advertisement that influences their Islamic practices. Thus, rendering the representation of Islam identity in advertisement is to reveal the meaning beyond the message of its text and context through visual and verbal language. To reveal what the advertisement meaning, thus some investigations are necessary.

In this paper, we would like to investigate two advertisements; they are Wardah make up and Resik-V Manjakani intimate wash as they are represented the identity of Islam including the relation of Islamic values, gender, and ideological patriarchy in the Indonesian veiled women. On the first advertisement; Wardah, presents the veiled woman who looks modest, modern, and fashionable with the current trends to sell a product. While, Resik-V Manjakani Intimate wash contains three essential values of veil for married women. First, pious wife is a great jewel. Second, women who use Resik-V Manjakani intimate wash indicate good wives. Third, a good wife is the secret of having sakinah (God-inspired peace of mind, transquility in family). Inspite of those images, thoughts and patriarchal ideology also play in Resik-V advertisement.

Based on the complex relation among religion (Islamic values), husband-wife (family relation), and consumption on TV advertisement in representing and revealing the identity of Islam, we questioned on how Islam identity is represented through Indonesian veiled women on TV's advertisements, particularly on Wardah make up and Resik-V Manjakani intimate wash.

\section{METHOD}

The method used in this study was descriptive qualitative using the concept of representation and the concept of identity by Stuart Hall. This was also applied the concept of patriarchal ideology to see the Indonesian women Muslim in Islamic perspective. The step to do was investigating two advertisements (Wardah make up and Resik-V Manjakani intimate wash) that revealed some issues about women in domestic area, Islamic identity, and consumption. Then, 
analyzing the text (script) on the advertisement through visual and verbal language based on its context and analyzed it with the concept of representation, identity, gender, and patriarchal ideology in the cultural study approach.

\section{RESULT AND DISCUSSION}

This part presented the representation of Islam identity through Indonesian veiled woman which is represented on two advertisements; Wardah Cosmetic and Resik-V Manjakani Intimate Wash Analysis. The first is Wardah. The script of the advertisement below showed a guidance in wearing veil and Islamic views. Wearing veil was not complicated; it was easy even for the beginners (who started wearing the veil). The Islamic values such as fasting and silaturahim were explicitly spoken. In Islam, both of them are important to have a good relationship with God and human. In addition, veil has significant meaning in Islam as it is the obligation mandated by Allah SWT written in the Holy Quran as in surah Al-Ahzab verse 59 and An-Nuur verse 31. Both verses are addressed particularly for all Muslim women and put a command that women should cover their hair with some kinds of head covering like veil to cover their aurat. Here is the text of Wardah advertisement,

"Pakai hijab itu semudah memakai lipstik loh tinggal satu, gaya 'Everyday Hijab' mudah digunakan bagimu yang baru menggunakan hijab. Dua, 'Hangout Hijab' gaya hijab yang diputar cocok untuk acara buka puasa bersama atau. Tiga 'Festive Hijab' hijab dengan ujung terikat cocok untuk silaturahmi. Apapun gayamu jangan lupa memakai wardah intens lipstik.”

\begin{abstract}
"Wearing the hijab is as easy as using a single live lipstick, the style of 'Everyday Hijab' is easy to use for you who just started wearing hijab. Two, the Hijab 'Hangout' of the hijab style that is rotated is suitable for breakfasting (with family or friends). Three 'Festive Hijab', hijab with a bound end is suitable for hospitality. Whatever your style is, do not forget to put Wardah intensely lipstick"
\end{abstract}

It is commonly known that the origin of hijab comes from Arab-Africa. It has been the new term in KBBI since 1990. The first name of hijab was called veil (kerudung) by MUI accordance with the begining of the popularity of wearing jilbab in the youth-urban Muslim women [11]. It is also the effect of the massive production of 'veil' Muslim fashion industry as commodities and linked to identity of Muslim women. In the text above, veil reproduced ways of looking not only indicated commercial message by showing some guides on how to use veil that addressed to veiled women and who wanted or started to wear veil but also alluded to the characteristic of modern forms of wearing style of the veil such as in Everyday Hijab, Hangout Hijab, Festive Hijab. Style of wearing the veil was played around with the convention of norm in Islam through the obligation of wearing veil. So that the advertisement of wardah cosmetic can invite an imagined women Muslim viewer to invest themselves in the 'look of beauty, pious, modesty, and modern' which was being presented by the model of the ads using media such as veil and lipstick. All women Muslim were, then, invited to buy the product as well as the 'look' of the beauty of the model in wardah cosmetic. In this case, the veiled women looked fashionable and stylish offered modern Muslim women either with the beauty of inner self of soul that comes from the pious and modesty in wearing veil as the obligation that is instructed in the Quran, keeping the relation with others (silaturahmi), and fasting or from the beauty of face on using the lipstick or make up.

The second advertisement was Resik $V$ manjakani intimate wash. We criticized why only women who were imposed and targeted in all products of intimate wash as in Resik- $V$ ? Or why the model of the product wasalways women, why not men? Thus, the products targeted women Muslim customers and ideology of patriarchy was put in this ad. The commercial TV's advertisements through its products placed veiled women on pedestal and have a good looking ideally based on male's perspective. The male's perspective on biological differences between men and women was depicted implicitly. Women intimate body is the sensitive and important area of the body where the womb takes place. It means women can give birth and continue in producing new generation. Therefore, the male's perspective about women is based on biological sex then creates and constructs the role of women. Women have gender role in domestic area to serve well their husband in bed. This concept of gender role has been too much deeper in Muslim male's perspective on how women to be, especially on the role of Indonesian wives in 'the realm of wells, mattresses, and kitchens.' The package of ideal Muslim women is seen clearly in the attached text of the advertisement,

"Perhiasan terindah adalah istri solehah. Dia selalu indah di mataku, rahasianya Resik- $V$ khasiat Manjakani Whitening. Resik-V dengan Manjakani dari Persia dan bengkoang pilihan terbukti dua kali mencerahkan, makin mengencangkan daerah kewanitaan. Resik-V cerahkan diriku, eratkan pernikahanku. Resik-V khasiat Manjakani Whitening rahasia keluarga sakinah."

"The greatest jewel is the solehah's wife (pious wife). She is always beautiful in my eyes, her secret is Resik- $V$ properties Manjakani Whitening. V-Resik with Manjakani from Persia and jicama (pachyrhizus erosus) proved twice enlightening, increasingly tighten the feminine area. Resik- $V$ enlightens me, tightens my marriage. Resik-V the merits of Manjakani Whitening is the secrets of a sakinah family."

In another, visual pleasure in women intimate body 
associated with the display of veil played in the representation. In this case, veiled women became the object of desiring look from side of male's perspective. The word 'the greatest jewel' used as metaphor to indicate pure, precious, and ideal that were directly pointed to women (wives). Meanwhile, women who used Resik-V Manjakani intimate wash meant that the ideal wives always paid attention for making the happiness of the marriage life through sexual intercourse and that was the way of the secret of having sakinah (the pursuit of happiness in family relation particularly wife-husband). Thus, the product was used as media to support a good wife and brought the Islamic values which had a great connection with patriarchal ideology. In Islam, women are demanded to give service for their husband, including sex intercourse. Using intimate wash could sometimes give happiness for the husband when they were having sexual intercourse. So, a good wife was a wife that can give happiness for her husband particularly on bed and that view was based on the patriarchal view. In spite of that, the practice of wearing veil as part of Islam identity which is shown by the veiled women tends to be passive. The veiled women are not given their right fully in controlling their body because the veiled women's body in Resik- $V$ ads is only packaged for male interest. Then, the husbands' treatment over their wives has a relative power and it contributes to the term of ideology of ideal wives.

Ideology of ideal wife in domestic area works on the male point of view as it is implied in the concept of ideal wife in Muslim family. The concept of ideal wife is to be a good wife ('Istri Sholehah'). Mulia said that the concept of a good wife in Indonesian Muslim is taken up from the religious teaching by Ulema or teacher at Islamic boarding school as stated in Uqul al-Lujayn book. In that book says one of the characteristic of ideal wife is to satisfy sexual desire of her husband [9]. That idea of ideal wife can be said as the control of husband through wife's body. Men construct the ideal body of women on reproduction health. The issue of reproduction health becomes the main issue in defining the ideal wife, since it is constructed by the social.

Finally, the point of result and discussion in Resik-V intimate wash were aimed at attracting an approving wife's look. The choice of the veiled women as a model, style of veil, and the product allude to a modern of representation of Islam identity and is taken up ideological patriarchy. What is worn by veiled women and displayed in commercial TV's advertisement either it is veil or the product of intimate wash. Those are served as commodity and desires for the view of husband through the ideal wife in the terms of religion.

\section{CONCLUSION}

Both of the two products in commercial TV's advertisements addressed their target to women Muslim customers in highly visual terms. The use of make-up, the use of veil or style in wearing veil as in Everyday Hijab, Hangout $H i j a b$, Festive Hijab, the beauty of the model and the veil look like 'covering hair', the visual and verbal text in both advertisements offered a particular kind of visual pleasure and spectacle in which the selling of the two products took part. Veil relates to the practice of fashion, style, and women Muslim consumption.

The veiled women on Wardah cosmetic advertisement represent the modesty, piety, and modernity in wearing veil as the parts of Islam identity. Modesty involves the obedience on following the religion instruction as mandated by the Holly Qur'an in surah surah Al-Ahzab verse 59 and An-Nuur verse 31 and it also brings the Islamic values in social life especially on how Muslim women should dress (covering their body and hair (aurat) and to have a good relationship with God and human by fasting and silaturahim. Piety could be both religious values in Islam (involved the obligation to cover aurat). Modernity refers to the development of fashion Muslim women in Indonesia, especially on how the veiled women used a certain style for the veil either for their daily activity or any special occasions. While, the Resik- $V$ ads showed a patriarchal ideology that stressed on the ideal Muslim women from the male's perspective (husband). The Resik- $V$ advertisement in representing Islam identity through Indonesian veiled women is projected and legitimized by the ideology of patriarchy. Ideology is imposed by dominant norms made by both of institution of Islam in defining the concept of a good wife and the husband in creating ideal wife in the family relation. That ideological patriarchy regulates the way or look of wives using veil and also social construction in gender role.

The use of veil on the commercial TV's advertisement can be analyzed with the semiotic theory in its connection with cultural studies. It would be given a new understanding on how the veil as a symbol can reveal the phenomenon of the increasing a veil user in Indonesia or in the other countries.

\section{REFERENCES}

[1] Barnard, Malcom. Fashion Sebagai Kominikasi, Cara Mengomunikasikan Identitas, Sosial Seksual, Kelas, Dan Gender (terjemahan). Yogyakarta: Jalasutra, 1996.

[2] Beta, A. R. "Hijabers: How Young Urban Muslim Women Redefine Themselves in Indonesia". International Communication Gazette, 76 (45), 377-389, 2014.

[3] El-Bassiouny, N. "The Hijabi Self: Authenticity and Transformation in TheHijab Fashion Phenomenon (No. 43)". Faculty of Management Technology. The German University in Cairo, 2016.

[4] Hassan, S., Harmimi Harun. "Factors Influencing Fashion Consciousness in Hijab Fashion Consumption Among Hijabistas". Journal of Islamic Marketing, 7(4), 476-494, 2016.

[5] Hall, S. Representation: Cultural Representations and Signifying Practices (Vol. 2). London: Sage Publications, 1997.

[6] Ihza, Yustiman, Bujuk Rayu Konsumerisme Menelaah Persuasi Iklan Di Era Konsumsi. Depok: Linea pustaka, 2013.

[7] Gilles, Judy and Middleton, Tim. Studying Culture: A Practical Introduction. Malden Massachusetts USA: Blackwell Publisher, 1999.

[8] Meuleman, Johan. South-East Asian Islam and the Globalization Process; Islam in the Era of Globalization. London \& Newyork: Routledge Curzon Taylor and Francis Group, 2002.

[9] Mulia, Siti Musdah. Islam dan Inspirasi Kesetaraan Gender. Yogyakarta: Kibar Press, 2007.

[10] Rosida, I. "Hasrat Komoditas di Ruang Urban Jakarta: Sebuah Kajian Budaya". Buletin Al-Turas, 20(1), 57-66, 2014.

[11] Prasetya, Heru, dkk. Pakaian, Gaya, dan Identitas Perempuan Islam; Identitas Perempuan Indonesia: Status, Pergeseran Relasi Gender, dan Perjuangan ekonomi Politik. Depok: Desantara Foundation, 2010. 